\title{
Measuring the quality of primary care in national health surveys: Lessons from Brazil
}

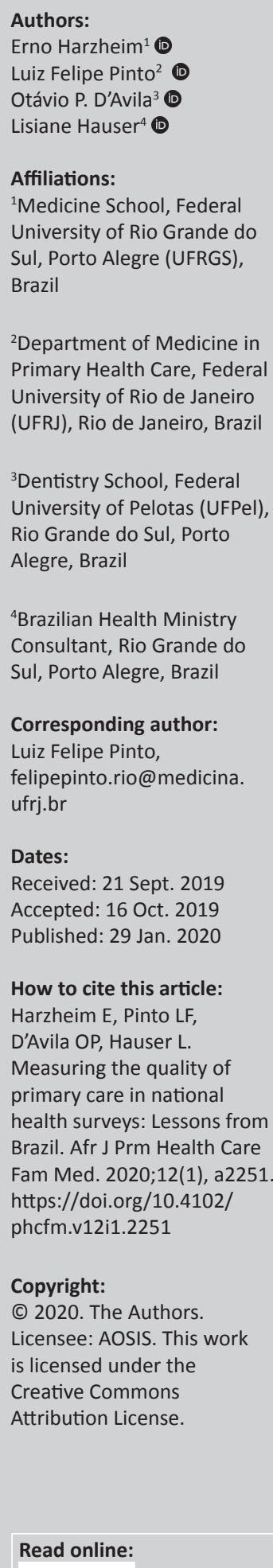

${ }^{2}$ Department of Medicine in Primary Health Care, Federal University of Rio de Janeiro (UFRJ), Rio de Janeiro, Brazil

${ }^{3}$ Dentistry School, Federal University of Pelotas (UFPel), Rio Grande do Sul, Porto Alegre, Brazil

${ }^{4}$ Brazilian Health Ministry Consultant, Rio Grande do Sul, Porto Alegre, Brazil

Corresponding author: Luiz Felipe Pinto, felipepinto.rio@medicina. ufrj.br

Dates:

Received: 21 Sept. 2019 Accepted: 16 Oct. 2019 Published: 29 Jan. 2020

How to cite this article: Harzheim E, Pinto LF, D'Avila OP, Hauser L. Measuring the quality of primary care in national health surveys: Lessons from Brazil. Afr J Prm Health Care Fam Med. 2020;12(1), a2251. https://doi.org/10.4102/ phcfm.v12i1.2251

\section{Copyright:}

(C) 2020. The Authors. Licensee: AOSIS. This work is licensed under the Creative Commons Attribution License.

\section{Read online:}

Background: South Africa started to lead the cross-culturally validation and use of the Primary Care Assessment Tool (PCAT) in Africa, when Professor Bresick filled a gap, as this continent was until then the only one that had never used it in evaluation of primary health care facilities until 2015.

Aim: The authors aim to demonstrate that after the consolidation of Bresick's team to an African version of PCAT, it had been adapted to household survey in Brazil.

Methods: In this letter, authors reflect on how Brazil had adapted PCAT to a national random household survey with Brazilian National Institute of Geography and Statistics (IBGE) - the Brazilian Census Bureau.

Results: In the the beginning of 2019, Brazilian Ministry of Health brought back the PCAT as the official national primary health care assessment tool. Brazilian National Institute of Geography and Statistics (IBGE) included a new module (set of questions) in its National Health Survey (PNS-2019) and collected more than 100000 households interviews in about $40 \%$ of the country's municipalities. This module had 25 questions of the Brazilian validated version of the adult reduced PCAT.

Conclusion: We believe that IBGE innovation with the Ministry of Health can encourage South Africa to establish a similar partnership with its National Institute of Statistics (Statistics South Africa) for the country to establish a baseline for future planning of primary health care, for decision-making based on scientific evidence.

Keywords: Africa; Brazil; primary health care; evaluation; PCAT.

\section{Introduction}

\section{South Africa's leadership in the use of Primary Care Assessment Tool on the African continent}

The questionnaires that form what is known as the Primary Care Assessment Tool (PCAT) were originally created by the team led by Professors Barbara Starfield and Leiyu Shi of Johns Hopkins Bloomberg School of Public Health for the evaluation of essential and derived attributes of primary healthcare services. ${ }^{1}$

In South Africa, between 2015 and 2019, Dr Bresick's team adapted and cross-culturally validated the PCAT, measured primary healthcare performance in the Western Cape and described differences between the experiences of users and staff with regard to primary care. ${ }^{2,3,4}$ This was the first time that PCAT was used in Africa (the SA PCAT). Since then, another African country, Malawi, has been inspired to follow in the footsteps of Bresick's team. ${ }^{5}$ The African researchers, just as Brazil did in 2006, when it started to lead and support other Latin American countries in the use of PCAT, could develop partnership with other countries in the continent.

In Brazil, the same questions and domains proposed by Professors Barbara Starfield and Leiyu Shi were maintained in the child and adult PCAT versions. ${ }^{6,7,8,9}$ The new questions in the ZA PCAT help us to reflect on the widening scope of primary healthcare, such as the possibility of referring to a physiotherapist, a mental health professional, a dietician or a social worker.

\section{Brazilian Institute of Geography and Statistics and the launch of the major national household survey using Primary Care Assessment Tools in the world}

Brazil was one of the first Latin American countries visited by Professor Barbara Starfield in 2002, when she launched her Portuguese book on primary healthcare. ${ }^{10}$ She also validated 
PCAT-Brazil with a team of researchers from southern Brazil and the Ministry of Health to publish it as an instrument for evaluating primary healthcare. ${ }^{6,11}$ The city of Porto Alegre, Rio Grande do Sul, was the first to apply PCAT in Brazil. ${ }^{6}$ Rio de Janeiro, the second major municipality in the country, remains the city in the world that interviewed people the most using the PCAT. In 2014, a group of researchers obtained data from a sample of 6675 users from municipal public health services. ${ }^{12}$

Since 1998, the Brazilian National Institute of Geography and Statistics (IBGE) has been conducting household surveys throughout the country, with probabilistic samples. These surveys, conducted every 5 years, contained a set of questions to investigate the health of the population. Then, in 2013, a new survey - the National Health Survey (Pesquisa Nacional de Saúde - PNS) - contained dozens of modules with specific questions about the health of children, women, the elderly, health service utilisation, etc. Since August 2019, data collection has included more than 100000 households and about $40 \%$ of the country's municipalities. ${ }^{13}$ One of the modules now has 25 questions from the Brazilian-validated version of the short PCAT ${ }^{14}$ and will be applied to adults aged over 18 years, from August 2019 to February 2020.

This will therefore facilitate the calculation of the general primary care score (the average of all items of the essential and derivative PCAT attributes). It will also allow the comparison of these scores by five regions and 27 federation units

As primary care researchers, we believe that this IBGE innovation with the Ministry of Health can encourage South Africa to establish a similar commitment from its National Institute of Statistics (Statistics South Africa) and the National Demographic and Health Survey to establish a baseline for future planning of primary care and for decision-making based on scientific evidence.

\section{Acknowledgements}

L.F.P. would like to thank the Institute of Hygiene and Tropical Medicine (IHMT) of the Universidade Nova de Lisboa, Lisbon, Portugal, for the opportunity to contribute to this scientific letter during his postdoctoral fellowship with Professor Zulmira Hartz (PhD).

\section{Competing interests}

The authors have declared that no competing interest exists.

\section{Authors' contributions}

All authors contributed equally to this work.

\section{Ethical considerations}

This article followed all ethical standards for a research without direct contact with human or animal subjects.

\section{Funding information}

This study received no specific grant from any funding agency in the public, commercial or not-for-profit-sectors.

\section{Data availability statement}

Data sharing is not applicable to this article as no data were created or analysed in this study. All data mentioned are cited in the references.

\section{Disclaimer}

The views and opinions expressed in this article are those of the authors and do not necessarily reflect the official policy or position of any affiliated agency of the authors.

\section{References}

1. Johns Hopkins Bloomberg School of Public Health. The Johns Hopkins Primary Care Policy Center. Primary care assessment tools [homepage on the Internet].
Baltimore, MD; 2016 [cited 2019 Oct 9]. Available from: http://www.jhsph.edu/ research/centers-and-institutes/johns-hopkins-primary-care-policy-center/pca_ tools.html

2. Bresick G, Sayed AR, Le Grange C, Bhagwan S, Manga N. Adaptation and crosscultural validation of the United States Primary Care Assessment Tool (expanded version) for use in South Africa. Afr J Prim Health Care Fam Med. 2015;7(1):e1-e11. https://doi.org/10.4102/phcfm.v7i1.783

3. Bresick G, Sayed AR, Le Grange C, Bhagwan S, Manga N, Hellenberg D. Western Cape Primary Care Assessment Tool (PCAT) study: Measuring primary care organisation and performance in the Western Cape Province, South Africa (2013). Afr J Prim and performance in the Western Cape Province, South Africa (2013). Afr J Prim
Health Care Fam Med. 2016;8(1):e1-e12. https://doi.org/10.4102/phcfm.v8i1.1057

4. Bresick G, Von Pressentin KB, Mash R. Evaluating the performance of South African primary care: A cross-sectional descriptive survey. SA Fam Pract. 2019;61(3):1-8. https://doi.org/10.1080/20786190.2019.1596666

5. Dullie L, Meland E, Mildestvedt T, Hetlevik $\varnothing$, Gjesdal S. Quality of primary care from patients' perspective: A cross sectional study of outpatients' experience in public health facilities in rural Malawi. BMC Health Serv Res. 2018;18:article number: 872. https://doi.org/10.1186/s12913-018-3701-x

6. Harzheim E, Starfield B, Rajmil L, Álvarez-Dardet C, Stein AT. Consistência interna e confiabilidade da versão em português do Instrumento de Avaliação da Atenção Primária (PCATool-Brasil) para serviços de saúde infantil. Cad Saúde Pública [serial Primária (PCATool-Brasil) para serviços de saúde infantil. Cad Saúde Pública [serial
online]. 2006 [cited 2019 Sep 9];22(8):1649-1659. Available from: http://www. online]. 2006 [cited 2019 Sep 9];22(8):16
scielo.br/scielo.php?script=sci_arttext \&p

7. Fontanive LT. Adaptação do instrumento Primary Care Assessment Tool-Brasil versão usuários dirigido à saúde bucal [Adaptation of the Primary Care Assessment Tool-Brazil users version addressed to oral health]. Dissertação de Mestrado Profissional (Professional Master's Degree). Porto Alegre, Rio Grande do Sul: Programa de Pós-Graduação em Epidemiologia, Universidade Federal do Rio Grograma de Pós-Graduação em Epidemiologia, Universidade Federal do Rio Grande do Sul, Brasil; 2011 [cite
ufrgs.br/handle/10183/53155

8. Cardozo DD. Validação e aplicação do PCATool-SB para avaliação da qualidade da atenção primária à saúde bucal - versão usuário. (Validation and application of [homepage on the Internet]. Tese de Doutorado [doctoral thesis]. Porto Alegre, Rio Grande do Sul: Faculdade de Odontologia, Universidade Federal do Rio Grande do Sul, Brasil; 2015 [cited 2019 Sep 21]. Available from: https://www. lume.ufrgs.br/handle/10183/133142

9. D’Avila OP. Avaliação de Serviços de Saúde Bucal na Atenção Primária a Saúde: Análise conceitual, psicométrica e exploratória [Evaluation of oral health services in primary health care: Psychometric and exploratory analysis]. Tese de Doutorado (doctoral thesis) [homepage on the Internet]. Porto Alegre, Rio Grande do Sul: Faculdade de Odontologia, Universidade Federal do Rio Grande do Sul, Brasil; 2016 [cited 2019 Sep 21]. Available from: https:// www.lume.ufrgs.br/bitstream/handle/10183/147161/000999280. pdf? sequence $=1$

10. Starfield B. Atenção primária: Equilíbrio entre necessidades de saúde, serviços e tecnologia [homepage on the Internet]. Brasil: Ministério da Saúde; 2002 [cited 2019 Sep 9]. [Original title: Primary Care: Balancing health needs, services, and technology. New York: Oxford University Press Inc.; 1998]. Available from: https:// unesdoc.unesco.org/ark:/48223/pf0000130805 
11. Brasil. Ministério da Saúde. Secretaria de Atenção em Saúde. Departamento de Atenção Básica. Manual do instrumento de avaliação da atenção primária à saúde: Primary Care Assessment Tool - PCATool - Brasil [homepage on the Internet]. Ministerio da Saúde, Secretaria de Atenção em Saúde, Departamento de Atenção Básica. Brasila: Minsterio da Saúde; 2010 [cited 2019 Sep 9]; 80p. Available from: http://bvsms.saude.gov.br/bvs/publicacoes/manual_avaliacao_pcatool_brasil.pdf

12. Harzheim E, Pinto LF, Hauser L, Soranz D. Assessment of child and adult users of the degree of orientation of Primary Healthcare in the city of Rio de Janeiro, Brazil. Ciênc Saúde Coletiva [serial online]. 2016 [cited 2019 Sep 19];21(5):1399-1408. Available from: http://www.scielo.br/pdf/csc/v21n5/en_1413-8123-csc-21-05-
13. Brazil. Federal University of Rio Grande do Sul (UFRGS). Launch of Fieldwork of Brazilian National Health Survey (PNS-2019) from Brazilian Institute of Geography and Statistics (IBGE) - TelessaúdeRS-UFRGS [homepage on the Internet]. [cited 2019 Sep 19]. Available from: https://www.ufrgs.br/telessauders/noticias/ launch-of-fieldwork-of-brazilian-national-health-survey-pns-2019-from-brazilianlaunch-of-fieldwork-of-brazilian-national-h
institute-of-geography-and-statistics-ibge/

14. Oliveira MMC, Harzheim E, Riboldi J, et al. PCATool-Adulto Brasil: uma versão reduzida [PCATool-Adult Brazil: A reduced version] [homepage on the Internet] Revista Brasileira de Medicina de Família e Comunidade [serial online]. 2013 [cited 2019 Oct 9];8(29). Available from: https://www.rbmfc.org.br/rbmfc/article/ view/823 